\title{
AFGHANISTAN NGO CEDAW SHADOW REPORT
}

September 2015

Address: Next to Naderya High School, Street \#1, House \#22, Kabul - Afghanistan www.awn-af.net info@awn-af.net Cell: +93777 743014 


$$
\text { pe }
$$




\section{AFGHANISTAN NGO CEDAW SHADOW REPORT}

\section{Acknowledgements}

AWN is grateful to the officials of the Ministry of Interior, the Ministry of Education, the Ministry of Higher Education, the Ministry of Health and the Ministry of Women's Affairs for participating in this research through interviews and the provision of statistical data. Special thanks are owed to the following women's rights civil society organizations (in alphabetical order) for informing this report: Afghan Community Service and Educational Organization (ACSEO), Afghanistan Society and Legal Organization (ASLO), Citizens Organization (CO), Paiwand Afghanistan and Training Human Rights Association (THRA).

\section{About Afghan Women's Network (AWN)}

The Afghan Women's Network (AWN) is a non-partisan, non-profit network of women that serves as an umbrella organization for 126 NGO members, and 3,500 individual members who are committed to supporting the women of Afghanistan. AWN has offices in Kabul, Herat, Jalalabad, Qandahar, Mazar-eSharif, Bamyan, Kunduz and Paktia. Primary concerns for AWN are issues related to: gender-based violence, youth empowerment and girl's education. The network also represents and promotes the views of Afghan women in political and social arenas through advocacy and by challenging Afghanistan's leaders to enforce legislative reforms for the protection of women's rights.

For more information, see: www.awn-af.net

Contact: director@awn-af.net director@awn-af.net 


\section{AFGHANISTAN NGO CEDAW SHADOW REPORT}

List of Abbreviations

$\begin{array}{ll}\text { AIHRC } & \text { Afghanistan Independent Human Rights Commission } \\ \text { ANDS } & \text { Afghanistan National Development Strategy } \\ \text { AWN } & \text { Afghan Women's Network } \\ \text { CEDAW } & \text { Convention of the Elimination of All Forms of Discrimination Against Women } \\ \text { DoWA } & \text { Directorate of Women's Affairs } \\ \text { EVAW } & \text { Elimination of Violence Against Women } \\ \text { FRU } & \text { Family Response Unit } \\ \text { GoA } & \text { Government of Afghanistan } \\ \text { MoE } & \text { Ministry of Education } \\ \text { MoFA } & \text { Ministry of Foreign Affairs } \\ \text { MoHE } & \text { Ministry of Higher Education } \\ \text { Mol } & \text { Ministry of Interior } \\ \text { MoJ } & \text { Ministry of Justice } \\ \text { MoPH } & \text { Ministry of Public Health } \\ \text { MoWA } & \text { Ministry of Women's Affairs } \\ \text { MP } & \text { Member of Parliament } \\ \text { NAPWA } & \text { National Action Plan for the Women of Afghanistan } \\ \text { NGO } & \text { Non-governmental Organization } \\ \text { TDR } & \text { Traditional Justice Resolution } \\ \text { UN } & \text { United Nations } \\ \text { VAW } & \text { Violence Against Women }\end{array}$




\section{AFGHANISTAN NGO CEDAW SHADOW REPORT}

\section{Table of Content}



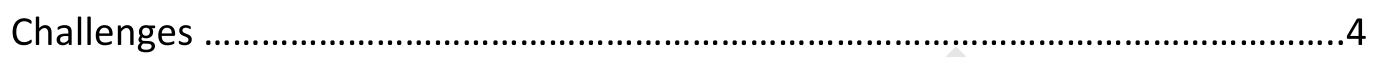

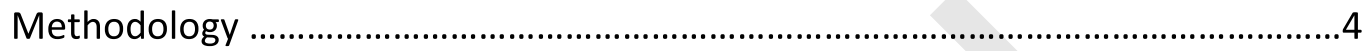

The Social and Political Context of Afghanistan....................................................

Article 1: Definition of Discrimination ...............................................................

Article 2: Condemnation of Discrimination and Remedial Measures ...................9

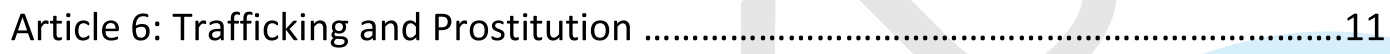

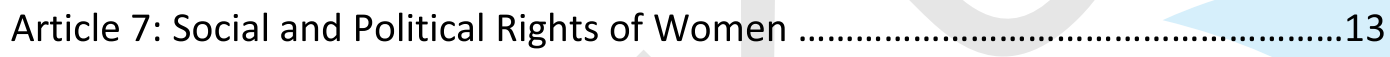

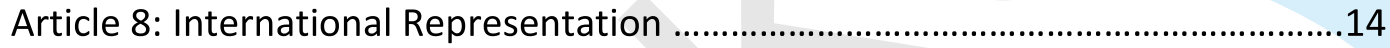

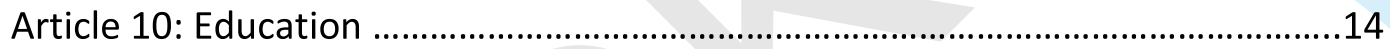

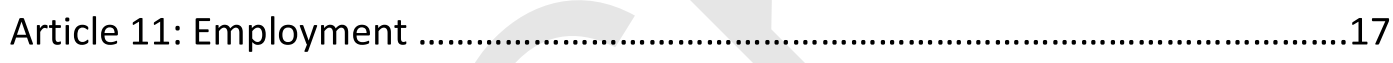

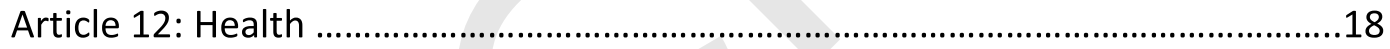

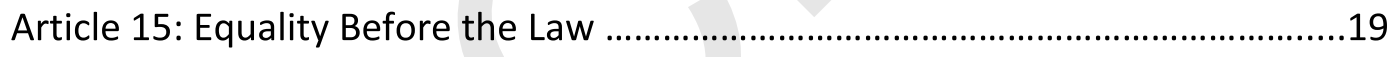

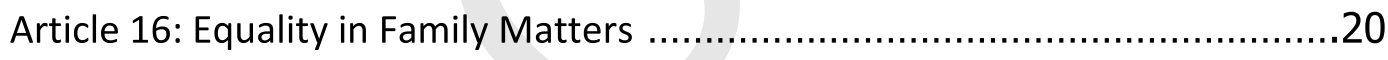




\section{AFGHANISTAN NGO CEDAW SHADOW REPORT}

\section{Introduction}

1. The Afghan Women's Network (AWN) wrote this NGO CEDAW SHADOW REPORT. The goal of the report is to provide analysis of issues that have been identified in the official government report submitted to the CEDAW Committee in 2011. The present report is a follow up report that focuses on the continued lack of implementation of existing laws and policy guidelines.

2. Key implementation gaps, which were identified in $A W N$ 's 2012 report, are still prevalent. Legislative frameworks and strategic documents still remain poorly implemented. The GoA needs to show stronger commitment to enforce Afghanistan's gender responsive laws and strategies in order to achieve meaningful change with regard to the elimination of discrimination against women.

\section{Challenges}

3. During data collection, the field researchers faced numerous challenges. In general, the security situation in the provinces was deteriorated due to clashes between armed opposition groups and the GoA security forces, which limited the mobility of the field researchers considerably.

4. Further, government officials were often not present when the field researchers visited them for an interview, despite the fact that interviews had been scheduled in advanced. The lack of cooperation on the part of local government officials was also faced as they, at times, would refuse to share information.

\section{Methodology}

5. A mixed method approach combining secondary and primary data analysis was adopted for the analysis of ten CEDAW articles relevant to the Afghan context. While the primary data was collected through face-to-face interviews in Kabul and in the provinces, the secondary data was accessed through online and desk-based literature reviews.

6. Data collection was carried out for the duration of two months between early May and late June 2015, though AWN's staff based in regional offices. The field researchers were trained and remotely overseen by AWN's Monitoring and Research Unit in the head office based in Kabul. A total of 18 Afghan provinces including Kabul were visited. In each province, the Afghan National Police (ANP) and the Family Response Units (FRUs), schools, health clinics, Directorates of Women's Affairs (DoWA), Departments of Higher Education (where available) and other government offices were visited to gather information for the analysis of articles 10 (Education), 12 (Health) and 15 (Equality Before the Law) in particular.

7. Survey data related to for example the number of female students and patients, number of female staff in schools, clinics and the FRUs as well as access of schools to basic amenities such as clean water 


\section{AFGHANISTAN NGO CEDAW SHADOW REPORT}

and electricity was asked during fieldwork.

\section{The Social and Political Context of Afghanistan}

8. Since the 2011 Bonn agreement, the promotion of gender equality has been a key crosscutting theme in reconstruction and development efforts in Afghanistan. As stated by the official CEDAW Report, submitted by the Government of Afghanistan, gender equality is enshrined in Afghanistan's constitution and the government has signed a range of international legal instruments aimed at promoting gender equality, including the Convention on the Elimination of Discrimination Against Women (CEDAW). ${ }^{1}$

9. Additional mechanisms for the promotion of gender equality include the Ministry of Women's Affairs (MoWA, established in 2002), the Afghanistan National Development Strategy (ANDS, finalized in 2008), the National Action Plan for the Women of Afghanistan (NAPWA, approved in 2008), and the Elimination of Violence Against Women law (EVAW, signed in 2009). In 2011, the government created a working group to develop a National Action Plan to implement Security Council Resolution 1325 on Women, Peace and Security, which was published in June $2015 .^{2}$

10. These documents and mechanisms are direct products of the formalization of gender mainstreaming in Afghanistan. The goal of gender equality reforms and programming has been to ensure that both men and women can exercise their rights, have opportunities to contribute to the reconstruction and development of the country, and enjoy a full and satisfying life. ${ }^{3}$ Since 2001 , women and girls have gradually increased their access to rights such as the right to education, healthcare and participation in public life. ${ }^{4}$

11. In April 2015, four new female ministers joined the 24-member Afghan cabinet. These female ministers are heading the Ministry of Women Affairs, Ministry of Counter Narcotics, Ministry of Higher Education and the Ministry of Labor and Social Affairs, Martyrs and the Disabled respectively. ${ }^{5}$ There is a mandatory 27 percent quota of women in the Parliament and another 20 percent of each provincial council at the subnational level. ${ }^{6}$ Currently, 24 percent of all government employees are women. ${ }^{7}$

\footnotetext{
${ }^{1}$ The Ministry of Rural Rehabilitation and Development of the Islamic Republic of Afghanistan (August 2011), Gender Policy, pages 6-8, mrrd.gov.af/Content/files/English Gender Policy Final\%282\%29.pdf

${ }^{5}$ Afghan Analysts Network (April 18, 2015), Afghanistan (almost) has a cabinet - MPs confirm all candidate ministers, www.afghanistananalysts.org/afghanistan-almost-has-a-cabinet-mps-confirm-all-candidate-ministers/

${ }^{6}$ The Quota Project, available at: www.quotaproject.org/uid/countryview.cfm?CountryCode=AF

${ }^{7}$ Central Statistics Organization, Afghanistan Statistical Yearbook 2013-14, www.cso.gov.af/en
} 


\section{AFGHANISTAN NGO CEDAW SHADOW REPORT}

12. Since the fall of the Taliban regime, Afghanistan saw the development of a women's rights movement. The Afghan Women's Network, for example, is the largest women's rights organization in Afghanistan with over 126 registered women rights organizations and some 3500 individual members that provide a range of services to women, including education, health, advocacy and legal support.

13. Statistics confirm that Afghanistan has the world's highest indicators of non-sexual violence against women and the lowest indicators for access to healthcare and economic resources for women. Early marriages are still highly prevalent in Afghanistan. According to 2011 statistics, 15.2 percent of Afghan women were married before the age of 15, whereas 43.2 percent got married before the age of 18 . Further, only 48 percent of all Afghan women had received antenatal care at least once during their pregnancy, while 65 percent of all child deliveries took place in the homes. With regard to education, the secondary school attendance ration for girls is 21 percent. $^{8}$

14. While the women's right to inherit land and control income in guaranteed in the constitution, this provision is poorly enforced, as women are denied their legal right to inherit by male relatives. ${ }^{9}$ Despite legal provisions and policy papers that protect women's rights in the economic and political spheres, mobility, marriage, divorce and inheritance, the lack of implementation of such laws and traditional customs that undermine women's rights continue to reinforce women's inequality in Afghanistan. ${ }^{10}$

\footnotetext{
${ }^{8}$ UNICEF (June 2012), Afghanistan Multiple Indicator Cluster Survey 2010-11, cso.gov.af/Content/files/AMICS-Jun24-2012-FINAL.pdf

${ }^{9}$ McClatchy DC (June 4, 2013), In Afghanistan, women denied their inheritance now have a champion, www.mcclatchydc.com/news/nationworld/world/middle-east/article24749644.html

${ }^{10}$ Foreign Affairs, Trade and Development Canada (June 16, 2015), Background Information: Promoting the Advancement of Women and Girls' Rights and Empowerment in Afghanistan, www.international.gc.ca/development-developpement/partners-partenaires/callsappels/afghanistan-bg.aspx?lang=eng
} 


\section{AFGHANISTAN NGO CEDAW SHADOW REPORT}

\section{Article 1: Definition of Discrimination}

15. AWN acknowledges that the key provisions of the law in Afghanistan protect women. Paragraphs 64 to 68 of the 2011 GoA CEDAW report outline laws that protect women in Afghanistan. The Constitution of Afghanistan asserts the equality of men and women under the law. Supporting laws, including the law on Elimination of Violence Against Women, prohibit discrimination against women and define violence. These laws alone provide a comprehensive framework that could protect women, if fully implemented.

16. However, this framework is undermined by a lack of enforcement and other laws that contradict the spirit of the Constitution and of other laws protecting women's rights. Some of the more recent examples are outlined below.

17. The EVAW law is frequently mentioned by the government as a key legal framework that defines violence against women (VAW) and which offer women legal protection. While the enforcement of this law is a major step towards the right direction, the poor implementation of the EVAW law has continued to be a serious concern in the country. The law enforcement (ANP) and justice officials alike continue to favor mediation over formal case referrals to the courts. VAW cases are often considered as private issues that need to be solved between family members or through the mediation of local community elders in community councils called shuras. Such traditional dispute resolution (TDR) mechanisms are not gender sensitized and may often take a stance against the rights of women. ${ }^{11}$

18. Women that run away from home to escape from due to reasons such as forced marriage or domestic violence are accused of committing so called moral crimes and imprisoned on the basis of attempted zina, which, according to the Afghan law, is illegal. ${ }^{12}$ In June 2014, the UN issued its Universal Period Report, recommending Afghanistan to stop its prosecution of women for running away from home. The GoA, however, rejected the recommendations from UN member countries. ${ }^{13}$

19. In June 2015, president Ghani nominated a female Supreme court Justice fulfilling one of his election promises. However, conservative forces including religious clerics and lawmakers proclaimed that women were not fit for this role. The female candidate lost the parliamentary vote by nine votes. ${ }^{14}$

\footnotetext{
11 UNAMA (December 2013), A Way to Go: An Update on Implementation of the Law on Eliminationof Violence against Women in Afghanistan, unama.unmissions.org/Portals/UNAMA/Documents/UNAMA REPORT on EVAW LAW 8 December 2013.pdf

12 Zina can be defined as sexual relationship between a man and a woman outside of marriage.

13 Human Rights Watch (2015), World Report: Afghanistan, www.hrw.org/world-report/2015/country-chapters/afghanistan

${ }_{14}$ Washington Post (July 27, 2015), Historic bid to become Afghanistan's first female justice falls nine votes short, www.washingtonpost.com/world/asia pacific/an-afghan-judge-was-nominated-to-the-supreme-court-trouble-is-shes-awoman/2015/07/27/bbb80a82-2ef3-11e5-818f-a242f28e7022 story.html
} 


\section{AFGHANISTAN NGO CEDAW SHADOW REPORT}

20. Recommendations for Article 1:

20.1 The implementation of the EVAW law should be strengthened through the abolition of mediation as a method to solve VAW cases. Further, the Mol, Attorney General's Office and the MoJ should instruct their staff to refer all VAW cases to the formal justice system.

20.2 The recommendation by the UN member countries to stop prosecuting women for so called moral crimes should be accepted by the GoA. 


\section{AFGHANISTAN NGO CEDAW SHADOW REPORT}

\section{Article 2: Condemnation of Discrimination and Remedial Measures}

21. The national constitution of Afghanistan is frequently mentioned in the GoA CEDAW report as one of the key documents that protect women against discrimination, as it states that all Afghans are equal before the law regardless of gender. Further, GoA mentions that the Ministry of Women's Affairs (MoWA) and Afghanistan Independent Human Rights Commission (AIHRC), which are two important organizations that fight discrimination against women, were established to help eliminating discrimination against women.

22. AWN acknowledges the establishment of key institutions that promote gender equality, including gender units in most ministries, and the importance of such steps to protect and empower women's role in the Afghan society. However, despite the adoption of significant remedial measures to mainstream gender, incidents that undermine the effort to eliminate gender discrimination continue to occur. One example is related to the damaged credibility of the AIHRC. The independence and reliability of AIHRC was recently called into question, as the UN High Commissioner for Human Rights raised concerns about whether the newly appointed commissioners met the eligibility criteria in line with the Paris Principles. ${ }^{15}$ There are also concerns raised about the lack of transparency and consultation in the commissioner selection process. The most serious criticism, however, pertains to lack of relevant experience and political partisanship among some of the commissioners that were appointed by president Karzai in June $2013 .{ }^{16}$

23. The GoA report also mentioned public statements against the discrimination of women by highranking political figures such as the president, ministers and the National Assembly. The established and approved laws, national policies, quotas and strategies that promote women's equality and rights are considered as significant progress in taking remedial measures to eliminate discrimination.

24. AWN commends all statements against the discrimination women made by politicians and other public figures. Moreover, AWN and other women's rights organizations appreciate the gender responsive laws and national policies that have been approved to further women's empowerment. Nevertheless, the failure to implement policies and laws continues to remain an issue in Afghanistan. This failure is to a large extent a result of shortages in resources, both financial and human, corruption and the lack of political will by decision makers in the states institutions. ${ }^{17}$

\footnotetext{
${ }^{15} \mathrm{OHCHR}$ (June 28, 2013), Pillay urges reconsideration of new appointments for the Afghan human rights commission, www.ohchr.org/EN/NewsEvents/Pages/DisplayNews.aspx?NewsID=13495\&LangID=E

${ }^{16}$ Afghan Analysts Network (June 16, 2013), AlHRC Commissioners Finally Announced, www.afghanistan-analysts.org/aihrc-commissionersfinally-announced/

${ }^{17}$ Amnesty International (April 6, 2015), Their Lives on the Line, www.amnestyusa.org/research/reports/their-lives-on-the-line
} 


\section{AFGHANISTAN NGO CEDAW SHADOW REPORT}

25. Recommendations for Article 2:

25.1 All appointments made of commissioners for the AIHRC or similar offices should be made transparently and through consultations with relevant actors including the Afghan civil society.

25.2 All ministries should follow the monitoring and budget instructions as outlined in the NAPWA, which state that at least 30 percent of all operational and development budgets should be allocated for gender responsive programming. 


\section{AFGHANISTAN NGO CEDAW SHADOW REPORT}

\section{Article 6: Trafficking and Prostitution}

26. The GoA country report of 2011 mentions various laws and international conventions, which Afghanistan has signed and ratified over the years. The Anti-Human Trafficking Law and the EVAW law are especially relevant in the context of article 6 and are frequently referred to in the government's report as one of the key measures taken to prevent trafficking and other forms of exploitation including prostitution.

27. Although the ratification of laws is a step towards the right direction, the correct implementation of such laws is necessary to achieve progress in the true sense. Early marriages and forced marriages of women and girls are still very common in Afghanistan. Laws such as the EVAW law and the AntiHuman Trafficking law are still not able to prevent such harmful practices. Government efforts to prevent human trafficking remains insufficient, as victims of trafficking continue to be convicted for so called moral crimes, while traffickers are allowed to escape legal prosecution and punishment. ${ }^{18}$ Key obstacles to the implementation of protection laws are for example a weak rule of law structure with a poorly functioning criminal justice system, high corruption levels within the justice system and a lack of political will to implement gender responsive laws and policies. ${ }^{19}$

28. Since the production of the GoA CEDAW report in 2011, serious rollbacks have taken place in women's access to legal protection. The EVAW law has been implemented in Afghanistan since 2009 through a presidential decree, criminalizing acts such as underage marriages, rape and forced prostitution. In May 2013, women's rights advocates, including the female lawmaker Fawzia Koofi, presented the EVAW law in the parliament, seeking its formal approval in order to strengthen its implementation and to send a positive signal to the women of Afghanistan showing that the parliament was supportive of women's rights. ${ }^{20}$ During the parliamentary debate, conservative lawmakers argued for the revocation of the law, calling it un-Islamic and incompatible with Afghan customs.

29. Conservative forces in the parliament also passed a new criminal code called article 26, which prohibits relatives of criminal defendants from witnessing against them. The purpose of his law is ultimately to prevent victims of domestic violence from speaking up against their perpetrators. ${ }^{21}$ The law was passed in both houses of the parliament and signed by President Karzai in February 2014, with an amendment narrowing down the definition of relatives. In its current form, article 26 only permits voluntary testimony by family members, including wives, sisters and daughters. Making the

\footnotetext{
${ }^{18}$ United States Department of State, 2014 Trafficking in Persons Report - Afghanistan, 20 June 2014, available at: http://www.refworld.org/docid/53aaba347a.html

${ }^{19}$ UNAMA (April 2015), Justice through the Eyes of Afghan Women: Cases of Violence against Women Addressed through Mediation and Court Adjudication, available at: http://unama.unmissions.org/Portals/UNAMA/UNAMA-

OHCHR/UNAMA OHCHR Justice through eyes of Afghan women - 15 April 2015.pdf

${ }^{20}$ Afghan Analysts Network (Mat 18, 2013), Damage Avoided, for Now? The very short debate about the EVAW law, available at:

https://www.afghanistan-analysts.org/damage-avoided-for-now-the-very-short-debate-about-the-evaw-law/

${ }^{21}$ Human Rights Watch (February 4, 2014), Afghanistan: Reject New Law Protecting Abusers of Women, available at:

https://www.hrw.org/news/2014/02/04/afghanistan-reject-new-law-protecting-abusers-women
} 


\section{AFGHANISTAN NGO CEDAW SHADOW REPORT}

testimony of relatives voluntary allows perpetrators of violence against women to prevent witnesses from testifying through intimidation. ${ }^{22}$

30. Recommendations for Article 6:

30.1 Protection laws, such as the Anti-Human Trafficking law and the EVAW law should be more vigorously implemented through proper legal investigations and prosecution of traffickers and perpetrators of violence against women.

30.2 Justice official should be prevented from prosecuting victims of forced prostitution and other forms of sexual violence for committing so called moral crimes.

30.3 The government of Afghanistan should establish civil justice committees to regularly monitor the activities of the law enforcement and justice officials to reduce corruption levels within the justice system.

30.4 Article 26 of the Criminal Code should be repealed as this article is currently undermining the implementation of the EVAW law, which is generally considered one of the greatest achievements for women's rights and protection.

${ }^{22}$ Human Rights Watch (March 20, 2014), Women's Rights in Afghanistan Must be Steadfastly Respected, available at: https://www.hrw.org/news/2014/03/20/womens-rights-afghanistan-must-be-steadfastly-respected 


\section{AFGHANISTAN NGO CEDAW SHADOW REPORT}

\section{Article 7: Social and Political Rights of Women}

31. The government states that all Afghans above the age of 18, regardless of gender, have a legal right to vote during elections. Further, women politicians take active role in the Afghan society, despite certain security threats and social barriers that limit their ability to reach out to the public.

32. However, barriers that prevent women's political participation are clear. The Election Law regulations, for example, prevent women from running for positions if they lack a certain degree of education. As women are already considerably disadvantaged, in terms of access to education and financial means especially, such regulations automatically lead to the disqualification of many women. The fact that, in 2010, very few women (9 percent) were holding decision making positions within the government is another confirmation of the lack of women in the higher ranks of GoA's state institutions.

33. Within the justice system, none of the nine Supreme Court justices are women. At the time of writing the GoA 2011 CEDAW report, 118 out of 2203 Afghan judges (5.4 percent) were women. Similarly, in 2010, Afghanistan had 75 female attorneys.

34. According to May 2014 data provided by the Supreme Court, Afghanistan had a total of 182 female judges. This figure suggests that between 2011 and 2014, Afghanistan gained 64 new female judges, which is a considerable progress. However, according to statistical data obtained from Attorney General's Office in Kabul, there were 108 female prosecutors in Afghanistan in early 2014, 77 (71.3 percent) out of which were based in Kabul. Considering that there were a total of 1796 prosecutors in total, female prosecutors only represent 6 percent of the total, the majority of which are based in Kabul. ${ }^{23}$ This information indicates that although there is a small increase in the number of women in the key positions of the justice system, the representation in the justice system remains marginal.

\section{Recommendations for Article 7:}

35.1 Each individual ministry should identify and appoint more qualified women to decision-making positions within the hierarchies of the government institutions to reach the 30 percent target as defined by the NAPWA.

35.2 Efforts should be increased by the Attorney General's Office, through affirmative action if necessary, to appoint more female law graduates as prosecutors until a minimum representation of 30 percent has been achieved.

35.3 The Supreme Court should make sure to train and appoint more female judges to reach a 30 percent representation.

\footnotetext{
${ }^{23}$ Source: Attorney General's Office, Kabul March-May 2014.
} 


\section{AFGHANISTAN NGO CEDAW SHADOW REPORT}

\section{Article 8: International Representation}

36. According to the GoA, the laws and regulations of Afghanistan do not discriminate against women's participation in international diplomatic missions. The GoA CEDAW report claims that capable female ministers, members of parliament (MPs) and members of Executive and Judicial offices represent Afghanistan in international conferences and forums. The report mentions that there were, at the time of producing the CEDAW report, ongoing efforts to increase women's role as representatives of Afghanistan, by including them more in delegations to regional and international conferences.

37. AWN commends the GoA's acknowledgement of the need to increase women's representation in international delegations and forums. However, although the need to increase women's participation is recognized, no clear strategy or targets are defined. The inclusion of civil society actors is especially important, if the international community is to hear the actual needs and concerns of Afghan women in the communities.

38. According to government estimations, in 2010, 84 out of 710 Ministry of Foreign Affairs (MoFA) staff were women (11.8 percent). Reasons for the low number of female staff included the lack of women with higher education in the field required by MoFA and family restrictions imposed on women, which prevent them from taking on international missions.

39. MoFA's explanations for the lack of female staff cannot be considered as satisfactory. As is demonstrated by other ministries, such as the Ministry of Education and Public Health with 29.7 and 23.9 percentage female staff respectively, qualified women can be found if adequate resources are placed in recruitment strategies. In addition, training and capacity development initiatives can be pursued to obtain a more ideal representation of women in this ministry. Currently, 101 out of MoFA's 1016 staff are women (9.9 percent). ${ }^{24}$ This figure indicates that the number of MoFA's female staff has slightly decreased between the years 2011 and 2014.

40. Recommendations for Article 8:

40.1 The GoA should make sure that Afghan women's rights organizations, that represent the women of Afghanistan at a grass roots level, are invited to participate in any future international event, along with other female officials, as part of the official delegation. The representation of civil society actors is especially important in matters related to the peace and security.

40.2 The MoFA should develop a recruitment plan with clear targets to increase women's representation in decision-making positions within the ministry in Afghanistan and in abroad missions.

\section{Article 10: Education}

41. According to the GoA's 2011 estimations, the literacy rate of the population was at 26 percent, while

${ }^{24}$ Central Statistics Organization, Afghanistan Statistical Yearbook 2013-14, www.cso.gov.af/en 


\section{AFGHANISTAN NGO CEDAW SHADOW REPORT}

the literacy rate among women was as low as 12 percent at the time of writing the 2011 CEDAW report. Only about 21.5 percent of all government schools were girls' schools and 37,3 percent of all children enrolled in grades 1-12 were female. The government also acknowledged that girls and boys study together in co-educational facilities until grade three and that girls only schools are necessary for girls to continue their education to higher grades.

42. Currently, the girls' school enrollment rate is 40 percent. Since 2011 the girl's enrollment has only increased by 2.5 percent. Moreover, in 2012, 32 percent of all general education teachers were female. By 2014 this figure had increased to 33 percent. As the GoA 2011 CEDAW report states, girls only schools are necessary in Afghanistan, especially in the higher grades, to encourage families to allow their girls to remain in school. However, official figures by the Afghan Central Statistics Organization show that, presently, less than 25 percent of all upper higher education schools are for girls, whereas roughly 43 percent are for boys and 32 percent are mixed with both boys and girls. ${ }^{25}$ Such figures show a significant gap in girls' access to education in Afghanistan.

43. With regard to women's access to higher education the government claimed that the low rate of girls' attendance in the university entrance exam was due to the high levels of insecurity. In 2009, only about 24.8 percent of all (public and private) university students were women. Similarly, only about 16.5 percent of the university lecturers were reported as being female. Dormitories had been established for 1510 female students across twelve out of thirty-four provinces. Furthermore, the Ministry of Higher Education had planned to establish dormitories for at least 50 percent of the female university students by 2015.

44. Figures provided by the Central Statistics Organization show that in 2015, 20 percent of all public university students are female, while 14,3 percent of all public university teachers are women. With regard to female students' access to dormitories, only 16.8 percent of all female students studying at a public university have access to dormitories in 2015. ${ }^{26}$ These figures indicate that the targets set by the Ministry of Higher Education to increase women's access to higher education institutions have not been achieved.

45. According to the 2011 CEDAW report of the GoA, female students are offered special opportunities, through affirmative action, to continue their education in Teacher Training Centers with slightly reduced score requirements and special bonuses. The purpose of this action is to create equal opportunities for female students, who tend to be more disadvantaged. In addition, efforts are made to encourage girls' education by offering food to families that send their girls to school. Further, schools are built near residential areas to reduce the walking distance, as this has been identified as one of the key obstacles to girls' access to education and a cause of high drop-out rates.

${ }^{25}$ Central Statistics Organization, Afghanistan Statistical Yearbook 2013-14, www.cso.gov.af/en

${ }^{26} \mathrm{Ibid}$. 


\section{AFGHANISTAN NGO CEDAW SHADOW REPORT}

46. AWN acknowledges that efforts have been made by GoA to improve girls' access to education. While, significant progress has been achieved, major challenges still remain in place. For example, in government technical and vocational institutes, 21 percent of all teachers are women, while the female students only make up 16.9 percent of the entire student population in these institutions. ${ }^{27}$ These figures reinforce the impression that the government of Afghanistan has failed to achieve meaningful progress with regard to improving women's access to general and higher education in Afghanistan.

47. Recommendations for Article 10:

47.1 The Ministry of Education should allocate more funds for the construction of girls' only lower and higher secondary schools, in rural parts of the country especially, to increase retention rates of female students beyond primary school.

47.2 More teacher training centers should be established at the provincial level and teacher candidates should be admitted from the local communities to create work opportunities at the local level.

47.3 The Ministry of Higher Education should revisit its targets to increase the number of dormitory facilities for female university students and consider allocating more funding to building more housing facilities for girls. 


\section{AFGHANISTAN NGO CEDAW SHADOW REPORT}

\section{Article 11: Employment}

48. The Afghan Constitution as well as several laws such as the Civil Service Law and the Labor Law of Afghanistan prohibit gender based discrimination in employment. According to GoA, the Civil Service Law controls conditions of civil servant recruitment and that civil servants are appointed based on experience, professional qualifications and education level in a competitive environment. The GoA CEDAW report further states that these provisions ensure equal payment without any discrimination between men and women.

49. Although the GoA report claims that the recruitment of civil servants is based on criteria such as the educations level, experience and professional qualifications of civil servant candidates, most Afghans perceive the recruitment process as unfair and corrupt. Research suggests that civil servants in Afghan governmental offices are often appointed based on personal relations or bribery. ${ }^{28}$ Such corrupt practices have an undeniable negative impact on women's access to employment in government offices.

50. The GoA report also acknowledges that there are factors that impede women's access to employment opportunities in government offices. These factors are identified as culturally conservative customs that do not approve of women working in public office and the poor implementation of the aforementioned labor laws. Moreover, GoA admits that, according to research, women who are entitled promotions will often be bypassed.

51. The role of female decision-makers in government institutions is generally perceived as symbolic and without political support. Women's position in leadership remains fragile and donor dependent. ${ }^{29}$ This is especially the case in rural Afghanistan where opportunities for women to take on leadership roles remain largely nonexistent.

\section{Recommendations for Article 11:}

52.1 To guarantee the access of women in decision-making positions in government offices and the 30 percent representation as defined by the NAPWA, an affirmative action plan should be developed, including gender quotas, at the department and unit levels of each ministry in every district of Afghanistan.

52.2 Every ministry should invest in capacity development opportunities, including longer-term training programs, for female employees to facilitate an effective promotion among female civil servants.

\footnotetext{
${ }^{28}$ Institute for War and Peace Reporting (December 31, 2014), Corruption Claimed in Afghan Civil Service Appointments, iwpr.net/globalvoices/corruption-claimed-afghan-civil-service-appointments

${ }^{29}$ USIP (September 2015), Women's Leadership Roles in Afghanistan, www.usip.org/sites/default/files/SR380-Women-s-Leadership-Roles-inAfghanistan.pdf
} 


\section{AFGHANISTAN NGO CEDAW SHADOW REPORT}

\section{Article 12: Health}

53. The Constitution requires that the GoA provide access to free healthcare services to all of Afghanistan's citizens. Afghanistan National Development Strategy (ANDS) is another key plan that has been endorsed and implemented since 2008. According to the ANDS targets, the Basic Package of Health Services would cover 90 percent of the Afghan population. Further, the maternity mortality rate would reduce by 21 percent from 1600 per 100.000 live births in year 2000, to 1264 in 2013. Likewise, the infant mortality rate would be reduced from 165 deaths per 1.000 live births to $115 .^{30}$

54. Significant efforts have been made and important progress has been achieved in the health sector of Afghanistan since the beginning of development efforts post 2001. The Basic Package of Health Services are currently reaching 85 percent of the population, Currently, 82 percent of the Afghan population is estimated as having access to some kind of basic health care services. ${ }^{31}$ By 2013 , the maternal mortality rate had reduced to 400 per 100.000 live births while the infant mortality rate had been reduced to 70 per 1.000 live births. ${ }^{32}$

55. These indicators show that the GoA has, to a large extent, achieved its ANDS health sector targets. However, challenges remain. Although women have improved access to basic healthcare, the quality level of the services remains considerably poor. Many Afghan's prefer to visit private clinics if they can afford it. Gaps in the quality of public health services include inappropriate behavior of medical staff, under-qualified staff, lack of medical supplies and long waiting times. Moreover, serious barriers continue to impede access to health facilities, such as distance and conflict. ${ }^{33}$

\section{Recommendations for Article 12:}

56.1 The MoPH should pay special attention to the quality of the public health services as well as quantity by setting clear quality criteria related to staff conduct, availability of medicine and staff qualifications.

56.2 The MoPH should carry out regular monitoring activities of all basic health service facilities across Afghanistan to ensure that the provided healthcare meets its general standards.

56.3 The MoPH should continue its efforts to reduce maternal and infant mortality rates in Afghanistan by increasing the number of skilled medical staff and availability of health facilities, as the maternal and infant mortality rates are still considerable higher than in neighboring countries.

\footnotetext{
${ }^{30}$ Afghanistan National Development Strategy (2008), Health and Nutrition Strategy, moph.gov.af/Content/Media/Documents/Strategy 200720082012 20138120111623351.pdf

${ }^{31}$ World Health Organization, www.emro.who.int/afg/programmes/primary-health-care-phc.html

32 Source: The World Bank, data.worldbank.org/indicator/SH.STA.MMRT

${ }^{33}$ Médecins Sans Frontières (February 2014), Between Rhetoric and Reality - The Ongoing Struggle to Access Healthcare in Afghanistan, www.doctorswithoutborders.org/sites/usa/files/attachments/afghanistan between rhetoric and reality.pdf
} 


\section{AFGHANISTAN NGO CEDAW SHADOW REPORT}

\section{Article 15: Equality Before the Law}

57. To demonstrate that the Afghan laws protect the equal rights of women and men, the GoA refers to Article 22 of the Constitution, which states that "all Afghan citizens, whether men or women, have equal rights and duties before the Law". Further, the government mentions in its report that the Afghan laws ensure that both men and women have access to the courts, police, attorneys and related justice institutions. However, the report also acknowledges that, in practice, the access to justice officials is limited. The lack of transportation, prevalence of illiteracy among rural women especially, and traditional customs are mentioned as barriers that women regularly face in their efforts to seek justice through the official justice system.

58. These barriers, mentioned by the GoA are still relevant. Women's access to justice in Afghanistan continues to be largely limited. Research shows that there is a strong preference among police and justice officials, such as prosecutors and judges, to solve VAW cases through mediation or through referrals to TDR mechanisms, i.e. local councils consisting of village elders. Mediation of VAW cases is ultimately a method that undermines the implementation of EVAW, and which reduces women's equal access to justice. ${ }^{34}$ In addition, the lack of female staff in the law enforcement, prosecution and courts make it more challenging for women to report their cases as male justice officials are not sensitized to women's situation and tend to show indifference towards their petitions. ${ }^{35}$

\section{Recommendations for Article 15:}

59.1 The ANP, AGO and Supreme Court should make sure that justice officials, including the police, prosecutors and judges, stop referring VAW cases to traditional dispute resolution mechanisms. Such cases must be prosecuted under the EVAW law.

59.2 The number of female prosecutors, judges and police in the ANP must be increased, since this would most likely encourage female survivors of gender based violence to report their cases as they would be more comfortable reporting to female justice officials.

\footnotetext{
${ }^{34}$ ActionAid (November 2014), Hanging in the balance: why the international community must redouble its commitment to Afghan women's rights, www.actionaid.org.uk/sites/default/files/publications/afghanistan briefing-final.pdf

35 UNAMA (December 2013), A Way to Go: An Update on Implementation of the Law on Eliminationof Violence against Women in Afghanistan, unama.unmissions.org/Portals/UNAMA/Documents/UNAMA REPORT on EVAW LAW 8 December 2013.pdf
} 


\section{AFGHANISTAN NGO CEDAW SHADOW REPORT}

\section{Article 16: Equality in Family Matters}

60. The Constitution and laws such as the EVAW law and the Family Protection Law are referred to by the GoA as provisions related to issue of equality in family matters. The government admits that despite the available legal framework that deals with family matters, most family disputes are solved though local councils where community elders assign the verdicts. In its 2011 report, the GoA admits that some of the decisions by local elders may be discriminatory against women.

61. While the existence of legal frameworks are of outmost importance to ensure equality between men and women in any society, strategies to cope with conservative forces, and a political will to stand up against traditional customs are of equal importance. In the case of Afghanistan, a national strategy to structurally change attitudes towards women's equal rights before the law is needed. VAW is often considered a domestic issue that should remain within the walls of the home. A woman that reports domestic violence through a formal petition is accused of bringing shame upon her family. Although the laws of Afghanistan protect women on paper, in reality, the situation regarding women's access to their legal rights looks very different and most women choose to remain silent. ${ }^{36}$

62. Under the issue of equality in family matters, the GoA discusses the question of dowry payments, which is defined by the GoA as "a financial amount that is committed by husband to pay to the wife for acceptance of marriage". The GoA acknowledges that, often, fathers and other close male relatives receive the dowry money, instead of the wife.

63. The dowry payment tradition in Afghanistan is harmful towards women as it reinforces the perception that women are products that can be bought and sold. The dowry tradition undermines women's status as equal citizens. Further, the dowry payment also encourages buying and selling of child brides. Although it is defines as a crime under the EVAW law, it is not uncommon for economically vulnerable families to give away their young girls as child brides in exchange for money. ${ }^{37}$

\section{Recommendations for Article 16:}

64.1 The government officials, including the President, MoJ, AGO, Mol and the Supreme Court should form joint initiatives to promote change in public opinion towards women's equality in the family through for example public statements and by presenting a united front as advocates of women's equal rights.

64.2 Justice officials should investigate cases more vigorously, prosecute and convict individuals that trade with female family members in exchange for bridal money (dowry).

${ }^{36}$ USIP (2014), Women's Access to Justice in Afghanistan - Individual Versus Community Barriers to Justice, www.usip.org/sites/default/files/PW98 Women's-Access-to-Justice-in-Afghanistan.pdf

${ }^{37}$ BBC (January 29, 2013), Naghma, the Afghan girl sold to be a child bride, www.bbc.com/news/world-asia-21245099 